\title{
Article \\ Tansy (Tanacetum vulgare L.) - A Wild-Growing Aromatic Medicinal Plant with a Variable Essential Oil Composition
}

\author{
Renata Nurzyńska-Wierdak, Andrzej Sałata *(D) and Magdalena Kniaziewicz
}

check for updates

Citation: Nurzyńska-Wierdak, R.;

Sałata, A.; Kniaziewicz, M. Tansy

(Tanacetum vulgare L.) - A

Wild-Growing Aromatic Medicinal

Plant with a Variable Essential Oil

Composition. Agronomy 2022, 12, 277.

https://doi.org/10.3390/

agronomy12020277

Academic Editor: Antonios

Chrysargyris

Received: 21 December 2021

Accepted: 19 January 2022

Published: 21 January 2022

Publisher's Note: MDPI stays neutral with regard to jurisdictional claims in published maps and institutional affiliations.

Copyright: (C) 2022 by the authors. Licensee MDPI, Basel, Switzerland. This article is an open access article distributed under the terms and conditions of the Creative Commons Attribution (CC BY) license (https:// creativecommons.org/licenses/by/ $4.0 /)$.
Department of Vegetable and Herb Crops, Faculty of Horticulture and Landscape Architecture, University of Life Sciences in Lublin, Doświadczalna Street 51A, 20-280 Lublin, Poland; renata.nurzynska@up.lublin.pl (R.N.-W.); magdalena.kniaziewicz@gmail.com (M.K.)

* Correspondence: andrzej.salata@up.lublin.pl

\begin{abstract}
Tansy (Tanacetum vulgare L.) is an aromatic medicinal plant whose use is limited by the presence of toxic thujone. This research aimed to evaluate the morphological and chemical properties of tansy plants growing in various natural habitats. The research determined the content and chemical composition of the essential oil, the contents of flavonoids and phenolic acids, and the antioxidant activity levels of methanol extracts from tansy inflorescences. The highest amount of essential oil $\left(1.05 \mathrm{~mL} \cdot \mathrm{kg}^{-1}\right)$ was found in the raw material collected from the reclaimed area (R). Forty-seven compounds were identified in tansy oil, among which camphor (31.21-1.27\%) and trans-chrysanthenyl acetate (76.09-0.09\%) dominated, while the concentration of trans-thujone was low $(2.67 \%$ on average). The highest amounts of flavonoids $(0.52 \%)$ were found in the raw material collected from the ruderal (W) and reclaimed (R) sites, while the highest amount of phenolic acids $(2.42 \%)$ was found in the raw material from the ruderal site $(\mathrm{W})$. Tansy inflorescence extracts showed high antioxidant potential $(88.41 \%)$. The reasons for the variability of the chemical composition of tansy were environmental and genetic variability factors.
\end{abstract}

Keywords: medicinal aromatic plant (MAP); biodiversity; essential oil; flavonoids; phenolic acids; antioxidant activity

\section{Introduction}

Tansy (Tanacetum vulgare L., syn. Chrysanthemum vulgare L.) is an intensely aromatic plant from the Asteraceae family, native to Europe and Asia, where it grows along roadsides, hedges, and wastelands. Medicines are made from the flower baskets of tansy (Tanaceti flos) and tansy herb (Tanaceti herba) containing $0.1-1.9 \%$ of essential oil, phenolic acids, flavonoids (derivatives of quercetin and luteolin), bitterness, and mineral compounds [1-3]. Tansy oil has a variable composition; its main components are beta-thujone, isomers, terpenes, camphene, beta-pinene, and others [4-6]. It is a yellowish-orange oily liquid with a warm, almost savory, spicy, dry, herbal odor. The oil accumulated in the flowers and leaves has a similar chemical composition. However, in some cases, the oil of the 1,8-cineole chemotype is accumulated in the leaves, and the inflorescences contain camphor oil or myrtenol oil. The content of 1,8-cineole in leaf oils is usually higher than in flower oils [1]. Stevović et al. [7] suggest that the variable composition of tansy essential oil is related to the high adaptability of this species to the environment. Coté et al. [8] report that T. vulgare essential oil has interesting biological properties, including anti-inflammatory, antioxidant, antibacterial, and cytotoxic effects.

T. vulgare is a poisonous plant, which was formerly used as a diuretic and antiparasitic drug. Due to the toxic effects of $\beta$-thujone, tansy flower extracts are mainly used externally as antiparasitic agents. In the traditional medicine of Southeast Serbia, tansy tea is used as an anthelmintic, carminative, antispasmodic, digestive-stimulant, antidiabetic, diuretic, and antihypertensive agent. Moreover, T. vulgare is conventionally used in lotions, 
cosmetics, dyes, insecticides, drugs, and preservatives [1]. Derda et al. [9] showed that alcoholic extracts of dried tansy herb have therapeutic properties against pathogenic and non-pathogenic strains of Acanthamoeba spp. and can be used with antibiotics to treat acanthamoeba keratitis. Devrnja et al. [10] showed that tansy extracts and low-thujone essential oil could be promising and effective alternatives in antimicrobial applications and food preservation. In subsequent studies [11], the authors suggested the potential of tansy plants to produce valuable chemicals in in vitro culture. Alizadeh et al. [12] indicated the still-existing folk and medical uses of tansy, and they even expressed concern that the intensive extraction of raw materials from natural habitats may cause the degradation of the plant's genetic resources.

In this study, we perform a morphological and chemical assessment of wild tansy plants, considering a comparative analysis of the content and composition of the essential oil of plants growing in various habitats. We also determine the contents of flavonoids and phenolic acids and the antioxidant activity of methanol extracts from tansy flowers.

\section{Materials and Methods}

\subsection{Plant Materials and Natural Habitats}

The research object was tansy plants (Tanacetum vulgare L.) growing in natural positions in eastern Poland (Wohyń Commune, Radzyń Poviat, Lubelskie Voivodeship) (Table 1). The plants had been botanically identified at the Department of Botany and Plant Physiology, University of Life Sciences in Lublin. Four sites were selected for the occurrence of tansy in larger clusters, characterized by different parameters (Table 1). The choice of the habitats was made based on the possibility of obtaining a representative sample of the raw material, the different soil conditions, the distances between the sites, and the visual assessment of the condition of the plants (Figure S1).

Table 1. Description of natural tansy sites covered in the research.

\begin{tabular}{|c|c|c|}
\hline Collection Site & Geographical Coordinates & Collection Site Description \\
\hline $\mathrm{R}$ & $51^{\circ} 45^{\prime} 13^{\prime \prime} \mathrm{N} 22^{\circ} 45^{\prime} 46^{\prime \prime} \mathrm{E}$ & $\begin{array}{l}\text { Land under reclamation, adjacent to the former landfill. } \\
\text { Sandy loam, fawn, light-colored soil with an admixture of } \\
\text { rusty, periodically flooded with excess rainwater, classified } \\
\text { as agricultural wasteland. Soil pH 5.5; fairly high light } \\
\text { exposure. Tansy plants in a compact arrangement among } \\
\text { sand reed (Calamagrostis epigejos (L.) Roth). }\end{array}$ \\
\hline M & $51^{\circ} 45^{\prime} 33^{\prime \prime} \mathrm{N} 22^{\circ} 46^{\prime} 54^{\prime \prime} \mathrm{E}$ & $\begin{array}{l}\text { A meadow bordering the Bobrówka River. The stand on a } \\
\text { small slope, located about } 40 \mathrm{~m} \text { from the river bed. Black } \\
\text { fertile, humus soil with a pH 7.5, classified as a class IV } \\
\text { meadow. High exposure to sunlight. The plant arrangement } \\
\text { is moderately compact. }\end{array}$ \\
\hline $\mathrm{W}$ & $51^{\circ} 44^{\prime} 56^{\prime \prime} \mathrm{N} 22^{\circ} 47^{\prime} 24^{\prime \prime} \mathrm{E}$ & $\begin{array}{l}\text { Ruderal position. Undeveloped area, after removing the top } \\
\text { layer of soil, periodically dry, with high exposure to } \\
\text { sunlight, classified as an agricultural wasteland. } \\
\text { Light-colored sandy loam soil, pH 5. Plant arrangement free, } \\
\text { loose, in proximity to field clover (Trifolium arvense L.) }\end{array}$ \\
\hline $\mathrm{T}$ & $51^{\circ} 45^{\prime} 28^{\prime \prime} \mathrm{N} 22^{\circ} 46^{\prime} 1^{\prime \prime} \mathrm{E}$ & $\begin{array}{l}\text { A shallow ditch by a road with moderate traffic, adjacent to } \\
\text { the plot classified as arable land of class V. Brown-sandy } \\
\text { soil, not uniformly brown, } \mathrm{pH} \text {. Moderate exposure to } \\
\text { sunlight. The plant arrangement is moderately compact, } \\
\text { with individuals of carrot (Daucus carota L.) nearby. }\end{array}$ \\
\hline
\end{tabular}

The area covered by the research is classified as the Masovian-Podlasie climatic region, the characteristic feature of which is the influence of the continental climate. The region typically experiences varied air temperature and large diurnal amplitudes, early and 
relatively long summers with a predominance of eastern winds, and a long winter with a predominance of frosty winds from the eastern direction [13].

Biometric measurements were made on 1 August 2017. The area of each plant cluster was determined $(\mathrm{R}-3.4 \times 4.0 \mathrm{~m}, \mathrm{~S}-2.5 \times 5.5 \mathrm{~m}, \mathrm{H}-2.6 \times 3.9 \mathrm{~m}, \mathrm{~T}-1.3 \times 8.8 \mathrm{~m})$. Morphological characteristics of tansy plants were assessed using the frame method, by analyzing the objects and collecting plant material from an area measuring $1 \mathrm{~m}^{2}$. Fifteen plants were randomly selected from each position, determining the height of the above-ground parts of the plant (from the soil surface to the top of the inflorescence), and then the inflorescences were cut manually (from the upper $4-5 \mathrm{~cm}$ of the shoot). Healthy, well-developed, colored, fully developed inflorescences, free from diseases and pests, were collected. After harvesting and determining the fresh weight of inflorescences, the raw material was dried in natural conditions, without access to light and with good air circulation (drying time was five days), and then weighed to assess the drying of the raw material. The drying ability of the tansy raw material was presented in the form of the dryness coefficient due to the more frequent use of this form of its presentation [14], by dividing the yield of fresh raw material by the yield of air-dried raw material.

\subsection{Chemical Analyses}

The air-dried tansy inflorescences (Figure S2) were subjected to chemical analyses, determining the content and composition of essential oils, flavonoids, and phenolic acids and the antioxidant activity of the extracts. All chemical analyzes were repeated in triplicate. All reagents and solvents were analytical-grade chemicals from Merck (Darmstadt, Germany), Sigma Chemical Co. (St. Louis, MO, USA), or POCH (Gliwice, Poland).

\subsection{Essential Oil Extraction}

Here, $20 \mathrm{~g}$ dried samples were subjected to water distillation for $3 \mathrm{~h}$ using Clevenger's apparatus [15]. The oils were dried with anhydrous sodium sulfate, filtered, and stored in a freezer at $-20{ }^{\circ} \mathrm{C}$ until the time of analysis.

\subsection{Qualitative and Quantitative Analyses of an Essential Oil}

For qualitative and quantitative analysis, an ITMS Varian 4000 GC-MC/MS instrument (Varian, Palo Alto, CA, USA) was used, equipped with a CP-8410 auto-injector and a $30 \mathrm{~m} \times 0.25 \mathrm{~nm}$ i. d. VF-5ms column (Varian, Palo Alto, CA, USA), under the following conditions: film thickness $=0.25 \mu \mathrm{m}$; carrier gas $=$ helium at a rate of $0.5 \mathrm{~mL} / \mathrm{min}$; injector and detector temperatures $=220^{\circ} \mathrm{C}$ and $200{ }^{\circ} \mathrm{C}$, respectively; split ratio $=1: 100$; injector volume $=1 \mu \mathrm{L}$. A temperature gradient was applied $\left(50^{\circ} \mathrm{C}\right.$ for $1 \mathrm{~min}$, then incremented by $4{ }^{\circ} \mathrm{C} / \mathrm{min}$ to $250{ }^{\circ} \mathrm{C}$ and held at this temperature for $10 \mathrm{~min}$ ) as follows: ionization energy $=70 \mathrm{eV}$; mass range $=40-1000 \mathrm{Da}$; scan time $=0.8 \mathrm{~s}$. The linear retention indices from temperature programming, using the definition of Van den Dool and Kratz [16], were determined for a series of n-alkanes $\left(\mathrm{C}_{6}-\mathrm{C}_{40}\right)$. The qualitative analysis was carried on the basis of MS spectra, which were compared with the spectra from the NIST library [17] and with data available in the literature [18]. The identities of the compounds were confirmed by their retention indices, as taken from the literature [18] and from our own data. The quantitative composition of the volatile oil was determined by assuming that the total of the percentages of all oil components was $100 \%$.

\subsection{Flavonoid Determination}

Flavonoids were determined using the Christ-Müller method [19]. For preparation of the stock solution, we weighed $1 \mathrm{~g}$ of the comminuted raw material, which was placed in a round-bottom flask, then $20 \mathrm{~mL}$ of acetone, $2 \mathrm{~mL}$ of $25 \%$ hydrochloric acid $(289 \mathrm{~g} / \mathrm{L})$, and $1 \mathrm{~mL}$ of an aqueous urotropine (methenamine) solution $(5 \mathrm{~g} / \mathrm{L})$ were added and kept for $30 \mathrm{~min}$ in a boiling water bath under a reflux condenser. The hydrolyzate was filtered through cotton wool into a $100 \mathrm{~mL}$ volumetric flask. The pad with cotton wool was placed in the flask, $20 \mathrm{~mL}$ of acetone was added, and it was refluxed again for $10 \mathrm{~min}$. The 
extraction was repeated, filtering the extract into the same volumetric flask and bringing the volume up to $100 \mathrm{~mL}$. Then, $20 \mathrm{~mL}$ of the solution was introduced into a separating funnel, $40 \mathrm{~mL}$ of distilled water was added, and the mixture was extracted twice with ethyl acetate into $20 \mathrm{~mL}$ portions. The resulting organic layers were filtered through cotton wool into a $50 \mathrm{~mL}$ volumetric flask and supplemented with ethyl acetate. Three samples of the test solution were prepared for each analyzed raw material collected from different stands. To $10 \mathrm{~mL}$ of the stock solution we added $2 \mathrm{~mL}$ of aluminum chloride methanol solution $(20 \mathrm{~g} / \mathrm{L})$, bringing the volume up to $25 \mathrm{~mL}$ with a mixture (1:19) of acetic acid $(1.02 \mathrm{~kg} / \mathrm{L})$ and methanol. A reference solution was prepared by supplementing $10 \mathrm{~mL}$ of the stock solution with a mixture (1:19) of acetic acid (1.02 kg/L) and methanol. After $45 \mathrm{~min}$, the absorbance of the solutions was measured in a spectrometer at a wavelength of $425 \mathrm{~nm}$, zeroing the apparatus against the reference solution. The total content of flavonoids converted to quercetin was calculated according to the following formula: $\mathrm{X}=(\mathrm{A} \cdot 0.875) / \mathrm{m}$, where $\mathrm{A}$ is the absorbance value of the tested solution and $\mathrm{m}$ is the weight of the raw material sample.

\subsection{Phenolic Acids Determination}

The method determined the total content of phenolic acids based on the proportional increase in color intensity of the solution relating to the content of phenolic acids in the test [20]. To prepare the sample, the crushed, sieved, and dried raw material was placed in a $250 \mathrm{~mL}$ round-bottom flask, then extracted three times with $50 \mathrm{~mL}$ of methanol in a water bath under a reflux condenser. The plant material was filtered off, methanol extracts from triplicate were mixed, and the solvent was distilled under reduced pressure. The residues were dissolved in $20 \mathrm{~mL}$ of hot water and left in the refrigerator for $12 \mathrm{~h}$. Precipitated ballast materials were filtered on filter paper and the solutions were transferred to volumetric flasks, bringing the volume up to $100 \mathrm{~mL}$ with distilled water. The test solution was prepared by measuring $1 \mathrm{~mL}$ of the previously obtained solution, $1 \mathrm{~mL}$ of distilled water, $1 \mathrm{~mL}$ of $0.5 \mathrm{M}$ hydrochloric acid, and $1 \mathrm{~mL}$ of Arnov's reagent $(10 \mathrm{~g}$ of sodium molybdate and $10 \mathrm{~g}$ of sodium nitrite dissolved in water and supplemented to $100 \mathrm{~mL}$ ) into measuring tubes with a capacity of $10 \mathrm{~mL}$. After $6 \mathrm{~min}, 1 \mathrm{~mL}$ of $0.1 \mathrm{M}$ sodium hydroxide was added, supplemented with $5 \mathrm{~mL}$ of distilled water. The mixture was quantitatively transferred to $1 \mathrm{~mL}$ cuvettes and determined spectrophotometrically at $490 \mathrm{~nm}$. The total contents of phenolic acids in terms of caffeic acid were calculated according to the following formula: $\mathrm{X}=(\mathrm{A} \cdot 3.5087) / \mathrm{m}$, where $\mathrm{A}$ is the absorbance value of the solution and $\mathrm{m}$ is the raw material weight.

\subsection{Antioxidant Activity}

Determination of the antioxidant activity (AA) of the tansy inflorescence extract was performed using the method described by Yen and Chen [21], consisting of colorimetric measurements of the reduction degree of the DPPH radical (2,2-diphenyl-1-picrylhydrazyl). The radical solution was prepared by weighing $0.012 \mathrm{~g}$ of 2,2-diphenyl-1-picrylhydrazyl and quantitatively transferring this to a $100 \mathrm{~mL}$ volumetric flask made up of methanol $(100 \%)$. The material was dissolved in an ultrasonic bath for 15 min. A blank $\left(\mathrm{A}_{\mathrm{r}}\right)$ was performed by measuring $1 \mathrm{~mL}$ of distilled water $(\mathrm{pH}>5), 3 \mathrm{~mL}$ of methanol $(100 \%)$, and $1 \mathrm{~mL}$ of DPPH solution. After stirring, the spectrometer gave a reading $(\lambda=517 \mathrm{~nm})$ after $10 \mathrm{~min}$. The test sample $\left(\mathrm{A}_{\mathrm{t}}\right)$ was prepared by measuring and combining $1 \mathrm{~mL}$ of sample, $3 \mathrm{~mL}$ of methanol (100\%), and $1 \mathrm{~mL}$ of DPPH solution. After $10 \mathrm{~min}$, the result was read at $\lambda=517 \mathrm{~nm}$ against methanol $(100 \%)$. The following formula was used for the calculation: $\% \mathrm{DPPH}=100-\left[\mathrm{A}_{t} / \mathrm{A}_{\mathrm{r}} \cdot 100\right]$, where $\mathrm{A}_{t}$ is the absorbance of the test sample and $\mathrm{A}_{\mathrm{r}}$ is the absorbance of the blank sample, which was 0.740 .

\subsection{Statistical Analysis}

The results of the morphological and chemical analyses were statistically processed using the analysis of variance method. Tukey's test was used to evaluate the differences, 
while the confidence intervals were calculated at the significance level of 0.01. All calculations and analyses were performed using Statistica 9.0 PL software (StatSof Inc., Tulsa, OK, USA).

\section{Results}

The wild-growing tansy plants were upright, leafy (large, pinnate, petiole, dark green leaves), and slightly branched at the top, ending with umbel inflorescences, with an even diameter of about $1 \mathrm{~cm}$. The flowers in the inflorescences were dark yellow. Whole plants had an intense, balsamic fragrance. The tansy plants were characterized by relatively strong growth (average height of $105 \mathrm{~cm}$ ), except for plants from the ruderal (W) site (Table 2). By analyzing the height of tansy plants and based on the calculated coefficient of variation $V$, it can be concluded that three of the selected sites were characterized by little variability, while the population growing on the ruderal site $(\mathrm{W})$ was heterogeneous. The fresh weight of tansy inflorescences and the weight of the dried material did not differ significantly. The dryness of the analyzed material of tansy was even and averaged 7.6.

Table 2. Plant height and inflorescence weight values of wild-growing tansy plants.

\begin{tabular}{|c|c|c|c|c|c|c|}
\hline \multirow{2}{*}{ Collection Site * } & Plant Height & Range & \multirow{2}{*}{$V^{* *}(\%)$} & Fresh Matter & Air-dry Matter & \multirow{2}{*}{$\mathbf{R}_{\mathbf{d}} * * *$} \\
\hline & \multicolumn{2}{|c|}{$(\mathrm{cm})$} & & \multicolumn{2}{|c|}{$\left(g \cdot\right.$ Plant $\left.^{-1}\right)$} & \\
\hline $\mathrm{R}$ & $141.0^{\mathrm{a}}$ & $129-151$ & 4.3 & $685.0^{a}$ & $89.0^{\mathrm{a}}$ & 7.7 \\
\hline M & $120.8^{b}$ & $109-127$ & 3.6 & $588.5^{\mathrm{a}}$ & $76.5^{a}$ & 7.6 \\
\hline W & $36.9^{c}$ & $19-62$ & 36.6 & $562.2^{\mathrm{a}}$ & $73.0^{\mathrm{a}}$ & 7.7 \\
\hline $\mathrm{T}$ & $121.4^{\mathrm{b}}$ & $117-125$ & 1.9 & $590.7^{a}$ & $76.8^{a}$ & 7.6 \\
\hline Mean & 105.0 & & & 595.0 & 77.5 & 7.6 \\
\hline
\end{tabular}

* The description of the collection site is given in Table $1 ;{ }^{* *}$ coefficient of variation $V=\mathrm{s} / \mathrm{x} \cdot 100 \%$, where $\mathrm{s}$ is the standard deviation of the sample, $x$ is the arithmetic mean of the sample, $x \neq 0$; ${ }^{* * *} R_{d}$ is the the raw material drying index calculated as the quotient of the weights of the fresh and dry raw materials; the means marked with the same letter do not differ significantly.

The tested raw material of tansy varied regarding the content of polyphenols (Table 3). The highest amounts of flavonoids $(0.52 \%)$ were found for the raw material collected from the ruderal $(\mathrm{W})$ and reclaimed $(\mathrm{R})$ sites, and the highest amount of phenolic acids $(2.42 \%)$ was found in the raw material from the ruderal site (W). The antioxidant activity (AA) of tansy inflorescences extracts was on average $88.41 \%$. The lowest AA $(87.48 \%)$ was found in the extract from the meadow bordering the river $(\mathrm{M})$.

Table 3. Polyphenol content (\%) and antioxidant activity (\%) values of tansy inflorescences extracts.

\begin{tabular}{cccc}
\hline Collection Site $^{*}$ & Total Flavonoids & Total Phenolic Acids & Antioxidant Activity ** \\
\hline R & $0.49^{\mathrm{ab}}$ & $1.87^{\mathrm{c}}$ & $88.69^{\mathrm{a}}$ \\
$\mathrm{M}$ & $0.45^{\mathrm{b}}$ & $2.15^{\mathrm{b}}$ & $87.48^{\mathrm{b}}$ \\
$\mathrm{W}$ & $0.52^{\mathrm{a}}$ & $2.42^{\mathrm{a}}$ & $88.42^{\mathrm{a}}$ \\
$\mathrm{T}$ & $0.38^{\mathrm{b}}$ & $1.68^{\mathrm{c}}$ & $88.78^{\mathrm{a}}$ \\
Mean & 0.46 & 2.03 & 88.41
\end{tabular}

* The description of the collection site is given in Table $1 ;{ }^{* *}$ DPPH inhibition value; means marked with the same letter do not differ significantly.

Tansy essential oil was characterized by a light, clear, slightly aquamarine color (Figure S3) and a warm, spicy-herbal scent. The content of essential oil in the tested raw material was $0.86 \mathrm{~mL} \cdot \mathrm{kg}^{-1}$ on average (Table 4). The richest in oil $\left(1.05 \mathrm{~mL} \cdot \mathrm{kg}^{-1}\right)$ was the raw material collected from the reclaimed area $(\mathrm{W})$. Forty-seven compounds were identified in the oil, among which the dominant components were camphor (31.21-1.27\%) and trans-chrysanthenyl acetate (76.09-0.09\%). A significant variation in the chemical composition of tansy oil was demonstrated. The share of trans-thujone in the analyzed oils was small and amounted to $2.67 \%$ on average. 
Table 4. Essential oil composition of wild-growing tansy plants (\%).

\begin{tabular}{|c|c|c|c|c|c|c|}
\hline \multirow{2}{*}{ No. } & \multirow{2}{*}{ Compound } & \multirow{2}{*}{ RI } & \multicolumn{4}{|c|}{ Collection Site * } \\
\hline & & & $\mathbf{R}$ & $\mathbf{M}$ & $\mathbf{W}$ & $\mathbf{T}$ \\
\hline 1. & santolina triene & 900 & 5.28 & 0.37 & 0.20 & $\operatorname{tr} * *$ \\
\hline 2. & tricyclene & 919 & 0.42 & 0.14 & 0.12 & $\operatorname{tr}$ \\
\hline 3. & $\alpha$-thujene & 923 & 0.10 & 0.25 & 0.19 & $\operatorname{tr}$ \\
\hline 4. & $\alpha$-pinene & 930 & 2.09 & 2.08 & 2.29 & 0.78 \\
\hline 5. & camphene & 946 & 2.33 & 1.86 & 2.06 & 0.18 \\
\hline 6. & sabinene & 970 & 2.09 & 3.39 & 2.36 & 0.24 \\
\hline 7. & $\beta$-pinene & 975 & 0.54 & 0.51 & 0.48 & $\operatorname{tr}$ \\
\hline 8. & yomogi alcohol & 993 & 3.48 & 0.11 & 0.09 & - \\
\hline 9. & $\alpha$-terpinene & 1013 & 0.24 & 0.43 & 0.36 & 0.10 \\
\hline 10. & o-cymene & 1020 & 0.80 & 0.69 & 1.02 & 0.47 \\
\hline 11. & limonene & 1024 & 0.85 & 0.53 & 0.64 & $\operatorname{tr}$ \\
\hline 12. & 1,8-cinolene & 1027 & 7.87 & 5.25 & 6.48 & 2.71 \\
\hline 13. & $\gamma$-terpinene & 1050 & 0.61 & 0.79 & 0.71 & 0.20 \\
\hline 14. & artemisia alcohol & 1070 & 0.78 & $\operatorname{tr}$ & - & - \\
\hline 15. & linalol & 1089 & 0.33 & 0.33 & 0.28 & 0.17 \\
\hline 16. & $\alpha$-thujone & 1095 & - & $\operatorname{tr}$ & 0.14 & - \\
\hline 17. & trans-p-mentha-2,8-dien-1-ol & 1104 & - & - & - & 5.39 \\
\hline 18. & trans-thujone & 1106 & - & 0.74 & 9.95 & - \\
\hline 19. & chryasanthenone & 1111 & 1.16 & 1.11 & 0.50 & 0.49 \\
\hline 20. & cis-sabinol & 1132 & 0.72 & 0.54 & 0.44 & 0.77 \\
\hline 21. & camphor & 1140 & 31.21 & 10.17 & 11.93 & 1.27 \\
\hline 22. & pinocarvone & 1157 & - & 1.01 & - & 1.12 \\
\hline 23. & cis-chrysanthenol & 1158 & 4.11 & - & 1.82 & - \\
\hline 24. & umbellulone & 1165 & - & 2.20 & - & 0.16 \\
\hline 25. & borneol & 1168 & 1.87 & 3.31 & 3.68 & - \\
\hline 26. & terpinen-4-ol & 1177 & 1.53 & 1.53 & 1.61 & 0.48 \\
\hline 27. & myrtenol & 1195 & 4.26 & 0.08 & 4.23 & 0.35 \\
\hline 28. & myrtenal & 1198 & - & 1.27 & 5.51 & $\operatorname{tr}$ \\
\hline 29. & trans-dihydrocarvone & 1204 & 0.23 & 6.61 & 20.62 & 0.10 \\
\hline 30. & neo-iso-dihydrocarveol & 1219 & - & 0.43 & 1.36 & - \\
\hline 31. & trans-chrysanthenyl acetate & 1232 & 0.09 & 37.54 & 0.92 & 76.09 \\
\hline 32. & carvone & 1245 & 0.65 & 0.51 & 1.44 & 0.06 \\
\hline 33. & cis-chrysanthenyl acetate & 1257 & 0.07 & 0.13 & 1.91 & 0.11 \\
\hline 34. & cis-verbenyl acetate & 1267 & 5.56 & - & - & 0.26 \\
\hline 35. & bornyl acetate & 1285 & - & 3.10 & - & - \\
\hline 36. & neo-iso-3-thujyl acetate & 1285 & 1.31 & - & 1.57 & - \\
\hline 37. & thymol & 1293 & - & 0.45 & - & - \\
\hline 38. & myrtenyl acetate & 1322 & 0.42 & 0.68 & 1.92 & 1.50 \\
\hline 39. & silphiperfolg-6-ene & 1366 & - & - & - & 0.41 \\
\hline 40. & germacrene D & 1491 & 0.46 & 0.42 & 0.70 & 0.38 \\
\hline 41. & bicyclogermacrene & 1507 & 0.63 & $\operatorname{tr}$ & $\operatorname{tr}$ & $\operatorname{tr}$ \\
\hline 42. & E-nerolidol & 1564 & 0.27 & 0.43 & 0.16 & $\operatorname{tr}$ \\
\hline 43. & spathulenol & 1579 & 0.78 & 0.90 & 1.07 & 0.56 \\
\hline 44. & caryophyllene oxide & 1584 & 0.85 & 0.50 & 0.97 & 0.45 \\
\hline 45. & salvial-4(14)-en-1-one & 1593 & 0.63 & 0.38 & 0.35 & 0.27 \\
\hline 46. & guaiol & 1611 & 0.56 & 0.51 & 0.83 & - \\
\hline 47. & $\alpha$-acorenol & 1634 & 0.62 & 0.66 & 1.18 & - \\
\hline Esse & al oil efficiency $\left(\mathrm{mL} \cdot \mathrm{kg}^{-1}\right)$ & & 1.05 & 0.8 & 0.9 & 0.7 \\
\hline
\end{tabular}

* The description of the collection site is given in Table $1 ;{ }^{* *}<0.05$.

The essential oil of the inflorescences obtained from the reclaimed site $(\mathrm{R})$ contained the most camphor $(31.21 \%), 1,8$-cineole $(7.87 \%)$, cis-verbenyl acetate $(5.56 \%)$, and santolina triene $(5.28 \%)$, and did not contain trans-thujone. The most abundant trans-dihydrocarvone $(20.62 \%)$ and trans-thujone $(9.95 \%)$ contents were found in the oil from the inflorescences of plants from the ruderal site $(\mathrm{W})$. This oil also had a significant $(6.48 \%)$ share of 1,8 -cineole. 
The most common oils obtained from the inflorescences of plants growing in the meadow near the river $(\mathrm{M})$ were trans-chrysanthenyl acetate $(37.54 \%)$ and camphor $(10.17 \%)$. These oils contained small amounts of trans-thujone $(0.74 \%)$ and bornyl acetate and thymol, compounds not found in the other oils. Plants growing along the road (T) accumulated oil with the highest share of trans-chrysanthenyl acetate $(76.09 \%)$, in which no trans-thujone was found. This oil contained trans-p-mentha-2,8-dien-1-ol (5.39\%), which was not found in the remaining samples.

The studied tansy chemotypes were characterized by a different chemical profile for the essential oil. Two of the tested oils did not contain cis- or trans-thujone. In the remaining cases, cis-thujone constituted $0.14 \%$, while the traces and trans-thujone constituted $0.74 \%$ and $9.95 \%$, respectively. Plants from the reclaimed area $(\mathrm{R})$ presented a camphor $/ 1,8$ cineole profile, plants growing in the meadow adjacent to the river $(\mathrm{M})$ presented a transchrysanthenyl acetate/camphor profile, plants from the ruderal site (W) presented a transdihydrocarvone/camphor/trans-thujone profile, and plants growing along the road (T) presented a trans-chrysanthenyl acetate profile.

\section{Discussion}

The genus Tanacetum includes aromatic plant species that are highly diversified in terms of morphology and chemistry [12], as confirmed by our results. The studied natural sites of tansy (Tanacetum vulgare), with specific and different soil and climatic conditions, were characterized by a more or less heterogeneous plant population. The tallest plants came from the reclaimed site $(R)$, where the highest essential oil yield was also found $\left(1.05 \mathrm{~mL} \cdot \mathrm{kg}^{-1}\right)$. Among the studied locations, the ruderal site $(\mathrm{W})$ should be noted, where the tansy plants constituted the most diverse community in terms of height, while at the same time being rich in essential oil $\left(0.9 \mathrm{~mL} \cdot \mathrm{kg}^{-1}\right)$.

Tansy is an aromatic plant rich in phenolic acids, flavonoids, and their derivatives, which contribute to the plant's pharmacological activity [1]. The herbal raw materials of tansy are the inflorescences (Tanaceti anthodium), although the literature lacks data on their chemical composition. Our research shows that wild tansy inflorescences contain essential oil $(0.9 \%)$, flavonoids $(0.46 \%)$, and phenolic acids $(2.03 \%)$, and their concentrations depend on the type of habitat. The inflorescences collected from the most heterogeneous site regarding plant height, namely the ruderal position (W) site, turned out to be the richest in flavonoids and phenolic acids. The extracts of tansy inflorescences we obtained were distinguished by high (88.41\%) antioxidant activity (AA). The AA of tansy extracts correlates well with the total polyphenol content $[2,10,22]$. Our results confirm that the presence of polyphenols may impact the AA of tansy inflorescence extracts.

Tansy herb (Tanaceti herba) harvested in the full flowering stage contains 0.1 to $0.5 \%$ of the essential oil [1]. In our research, the essential oil content was higher $(0.7-1.05 \%)$, which could be explained by obtaining the oil from the inflorescences and not from the whole aerial parts. Tansy plants exhibit a rich chemical profile of essential oil. More than 15 different chemotypes of tansy from Scandinavia and the Baltic have been described, with most researchers identifying $\beta$-thujone, trans-thujone, camphor, and chrysanthenyl acetate as the main components of the oils of plants from various habitats around the world [1]. The tansy plants we studied did not show the thujone chemotype (67.6-71.5\% $\alpha$-thujone, up to $13.4 \%$ $\beta$-thujone), described by Mockute and Judzentiene [23] in the Vilnius region. Judzentiene and Mockute [24] showed that the oil obtained from inflorescences and leaves had the same dominant components of 1,8-cineole (23.6-46.3\%, 11 oils), trans-thujone (35.7-78, $4 \%$, six samples), camphor (19.8-61.8\%, 17 oils), and myrtenol (13.1-24.9\%, six samples). The amounts of 1,8-cineole in all leaf oils were greater than in the inflorescence oils; an inverse correlation was found for camphor, myrtenol, and cis- and trans-thujone. The inflorescence oil samples we analyzed generally contained high amounts of camphor and 1,8-cineole and low amounts of cis- and trans-thujone, myrtenol, and myrtenal. It is worth paying attention to trans-chrysnathenyl acetate, a significant share of which (37.54 and $76.09 \%$ ) was determined for two tansy chemotypes. This compound is present in tansy oil 
within wide limits (0-41.62\%) and is not often described as the dominant component [1]. Di Napoli et al. [25] showed that the oil extracted from Anthemis secundiramea flowers containing (+)-(E)-chrysanthenyl acetate has antimicrobial properties against Gram-positive and Gram-negative bacteria, inhibits biofilm formation, has antioxidant activity, and may have antimicrobial properties, which are potentially relevant for topical, cosmetic, and nutraceutical applications.

Chemical polymorphism, which modifies the production of secondary metabolites among aromatic plants, is a widely described phenomenon [4,26]. Several aromatic plant chemotypes have been identified, but they have not yet been unequivocally linked to possible causes [26]. The tansy habitats we examined differed in terms of soil type, fertility and reaction, light conditions, and humidity conditions. $M$ and $W$ were found to be the best in terms of light conditions, and in terms of humidity $\mathrm{R}$ and $\mathrm{M}$ were best. Light is responsible for increasing the concentrations of monoterpenes and phenylpropanes $[27,28]$. The opposite is sometimes reported, whereby the concentrations of camphene, sabinene, $\beta$-pinene, borneol, bornyl acetate, and Z-jasmone may be higher in plants grown in partial shade than in full light [29]. Increased water availability stimulates the production of monoterpenes [30,31], although some data indicate a possible increase in monoterpenes with low water availability [32]. In our research, trans-chrysanthenyl acetate, a representative of monoterpenes, dominated (37.54 and 76.09\%) in the oil of two tansy chemotypes from $\mathrm{M}$ and $\mathrm{T}$, with different light and humidity conditions. Plants presenting a mixed trans-chrysanthenyl acetate/camphor profile, on the other hand, came from the places with the best light and humidity conditions. Palà-Paùl et al. [33] found that the distribution of terpenes was influenced by soil $\mathrm{pH}$; the population of Erygium campestre (Apiaceae) growing in acidic soil contained more myrcene and significantly less $\beta$-curcumene than the population growing in alkaline soil. Our research shows that more trans-chrysanthenyl acetate was accumulated by plants growing in alkaline and neutral soils rather than acidic soil. The share of camphor in tansy oil was higher in plants inhabiting acidic sites than in other plants. The concentration of 1,8-cineole, known for its antimicrobial activities [34], was higher $(7.87 \%$ and $6.48 \%)$ in the plant oil in the acidic position than in the alkaline $(5.25 \%)$ and neutral $(2.71 \%)$ positions. Likewise, another representative of the trans-dihydrocarvone monoterpenoids dominated (20.62\%) in the plant oil of the acid territory. The main limitation in using tansy oil and the raw material is the presence of thujone. Formisano et al. [35] described T. vulgare subsp. siculum as a thujone chemotype, suggesting that the high thujone content could explain the high sun exposure of plants. Our results confirmed that the chemotype containing the highest amount of thujone in the oil $(9.95 \%)$ came from a habitat with high light exposure.

On the other hand, plants found in environmentally different places were characterized by similar amounts of camphor, which may suggest genetic reasons. Oils containing similar amounts of camphor (10.17 and $11.93 \%$ ) were obtained from plants $\mathrm{t} \mathrm{M}$ and $\mathrm{W}$ sites with different environmental conditions, being alkaline and acidic soils, respectively, with high and moderate light exposure. At the same time, different levels of camphor (31.21 and $11.93 \%$ ) were characteristic for plants of similar areas in terms of environmental conditions ( $\mathrm{R}$ and $\mathrm{W})$. Another example is trans-dihydrocarvone, occurring in higher amounts (6.61 and $20.62 \%$ ) in plant oils from different environmental areas ( $\mathrm{M}$ and $\mathrm{W})$. Therefore, it can be assumed that the concentration of camphor or trans-dihydrocarvone in tansy oil is modified to a lesser extent by environmental factors, such as genetic factors. Hyeon et al. [36] showed that the differences and correlations of essential oil components, phenolic acids, and primary metabolites depended on common or closely related metabolic pathways, which supports the above supposition.

An essential aspect of this problem is the adaptability of tansy, which is most likely related to the presence of certain compounds in the oil [7]. According to these authors, the amount and composition of the essential oils of plants growing in industrial areas and in green areas can serve as indicators of the adaptability of this species to anthropocentric and anthropogenic environmental conditions and its usefulness. Our results for the varied 
tansy chemotypes from a reclaimed meadow, ruderal, and roadside sites strongly support this hypothesis. The protective role of volatile substances should also be considered here, an example of which is the increased levels of terpenoids (in particular L-camphor) in response to the presence of pests [37].

\section{Conclusions}

The wild-growing tansy plants turned out to be a valuable and varied source of bioactive substances. Tansy inflorescence extracts showed high antioxidant potential. The reasons for the variability of the chemical composition of tansy can be found in the environmental and genetic variability; therefore, further research should include molecular analyses.

Inflorescences collected from the most heterogeneous sites regarding plant height (ruderal area (W)) were the richest in flavonoids and phenolic acids. The essential oil of these inflorescences contained the most toxic trans-thujone, although this value did not exceed $10 \%$. The highest plant inflorescences from the reclaimed area (R) showed the highest essential oil yield.

The tansy plants examined here presented 4 chemotypes: camphor/1,8-cineole, transchrysanthenyl acetate/camphor, trans-dihydrocarvone/camphor/trans-thujone, and transchrysanthenyl acetate. Particularly interesting was the thujone-free chemotype, rich in 1,8-cineol and camphor, and the equally interesting chemotype of trans-chrysanthenyl acetate, also without thujone.

Supplementary Materials: The following supporting information can be downloaded at: https: / / www.mdpi.com/article/10.3390/agronomy12020277/s1. Figure S1: Natural sites of tansy, from above and from left to right: R, M, W, T (explanation in Table 1). Figure S2: Dried tansy raw material (Tanaceti inflorescences). Figure S3: Tansy essential oil (Tanaceti oleum).

Author Contributions: Conceptualization, A.S., M.K.; methodology, R.N.-W., A.S.; software, A.S.; validation, R.N.-W.; formal analysis, A.S., M.K.; investigation, M.K., A.S.; resources, M.K.; data curation, A.S., M.K.; writing—original draft preparation, R.N.-W., M.K.; writing-review and editing, R.N.-W.; visualization, R.N.-W., M.K.; supervision, R.N.-W., A.S.; project administration, A.S.; funding acquisition, R.N.-W. All authors have read and agreed to the published version of the manuscript.

Funding: This research received no external funding.

Institutional Review Board Statement: Not applicable.

Informed Consent Statement: Not applicable.

Data Availability Statement: Not applicable.

Conflicts of Interest: The authors declare no conflict of interest.

\section{References}

1. Aćimović, M.; Puvača, N. Tanacetum vulgare L.-A Systematic Review. J. Agron. Technol. Eng. Manag. 2020, 3, 416-422.

2. Sowa, P.; Marcinčáková, D.; Miłek, M.; Sidor, E.; Legáth, J.; Dżugan, M. Analysis of cytotoxicity of selected Asteraceae plant extracts in real time, their antioxidant properties and polyphenolic profile. Molecules 2020, 25, 5517. [CrossRef] [PubMed]

3. Konieczny, M.; Ślęzak, E. The influence of the environment on the content of macro- and microelements in the Tanacetum vulgare. J. Ecol. Eng. 2019, 20, 1-7. [CrossRef]

4. Piras, A.; Falconieri, D.; Bagdonaite, E.; Maxia, A.; Goncalves, M.J.; Cavaleiro, C.; Salgueiro, L.; Porcedda, S. Chemical composition and antifungal activity of supercritical extract and essential oil of Tanacetum vulgare growing wild in Lithuania. Nat. Prod. Res. 2014, 28, 1906-1909. [CrossRef]

5. Raal, A.; Orav, A.; Gretchushnikova, T. Essential oil content and composition in Tanacetum vulgare L. herbs growing wild in Estonia. J. Essent. Oil Bear. Plant. 2014, 17, 670-675. [CrossRef]

6. Solis-Quispe, L.; Solis-Quispe, J.A.; Aragon-Alencastre, L.J.; Fernández, M.D.; Hernández, I.; Rodeiro, I.; Pino, J.A. Composición química y actividad antioxidante de aceites esenciales de Tanacetum vulgare y Mentha x piperita L. var. vulgaris cultivados en Cusco, Perú. Rev. CENIC Cienc. Químicas 2017, 48, 41-47.

7. Stevović, S.; Mikovilović, V.; Ćalić-Dragosavac, D. Environmental adaptibility of tansy (Tanacetum vulgare L.). Afr. J. Biotechnol. 2009, 8, 6290-6294. 
8. Coté, H.; Boucher, M.A.; Pichette, A.; Legault, J. Anti-inflammatory, antioxidant, antibiotic, and cytotoxic activities of Tanacetum vulgare L. essential oil and its constituents. Medicines 2017, 4, 34. [CrossRef] [PubMed]

9. Derda, M.; Hadaś, E.; Thiem, B.; Wojt, W.J.; Wojtkowiak-Giera, A.; Cholewiński, M.; Skrzypczak, Ł. Tanacetum vulgare L., jako roślina o potencjalnych właściwościach leczniczych w Acanthamoeba keratitis. Now. Lek. 2012, 81,620-625.

10. Devrnja, N.; Anđelković, B.; Aranđelović, S.; Radulović, S.; Soković, M.; Krstić-Milošević, D.; Ristić, M.; Calić, D. Comparative studies on the antimicrobial and cytotoxic activities of Tanacetum vulgare L. essential oil and methanol extracts. S. Afr. J. Bot. 2017, 111, 212-221. [CrossRef]

11. Devrnja, N.; Krstić-Milošević, D.; Janošević, D.; Tešević, V.; Vinterhalter, B.; Savić, J.; Calić, D. In vitro cultivation of tansy (Tanacetum vulgare L.): A tool for the production of potent pharmaceutical agents. Protoplasma 2021, 258, 587-599. [CrossRef] [PubMed]

12. Alizadeh, M.A.; Jafari, A.A.; Sayedian, S.E. Evaluation of aerial biomass yield and essential oil content of seven species of Tanacetum. J. Hortic. Res. 2017, 25, 19-25. [CrossRef]

13. Boguszewski, R.; Rutkowski, T.; Borowiec, E. Program Rozwoju Gminy Wohyń na Lata 2015-2023; EuroCompass Sp.: Wohyń, Poland, 2015; pp. 9-10.

14. Gruszecki, R.; Zawiślak, G.; Rybiński, M.; Zalewska, E.; Walasek-Janusz, M. Usychalność surowców zielarskich (Drying ratio of herbal raw materials). Ann. Hort. 2020, 30, 5-21. [CrossRef]

15. Urząd Rejestracji Produktów Leczniczych, Medycznych i Produktów Biobójczych. Farmakopea Polska X (Polish Pharmacopoeia X); Urząd Rejestracji Produktów Leczniczych, Medycznych i Produktów Biobójczych: Warszawa, Poland, $2014 ;$ p. 4009.

16. Van Den Dool, H.; Kratz, P.D. A generalization of the retention index system including linear temperature programmed gas-liquid partition chromatography. J. Chromatogr. A 1963, 11, 463-471. [CrossRef]

17. NIST/EPA/NIH Mass Spectral Library; Wiley: Hoboken, NJ, USA, 2008.

18. Adams, R.P. Identification of Essential Oil Compounds by Gas Chromatography/Quadrupole Mass Spectroscopy; Allured Publishing Corporation: Carol Stream, IL, USA, 2004.

19. Urząd Rejestracji Produktów Leczniczych, Medycznych i Produktów Biobójczych. Farmakopea Polska VI (Polish Pharmacopoeia VI); Urząd Rejestracji Produktów Leczniczych, Medycznych i Produktów Biobójczych: Warszawa, Poland, $2002 ;$ p. 5023.

20. Urząd Rejestracji Produktów Leczniczych, Medycznych i Produktów Biobójczych. Farmakopea Polska V (Polish Pharmacopoeia V); Urząd Rejestracji Produktów Leczniczych, Medycznych i Produktów Biobójczych: Warszawa, Poland, $1999 ;$ p. 3985.

21. Yen, G.C.; Chen, H.Y. Antioxidant activity of various tea extracts in relation to their antimutagenicity. J. Agric. Food Chem. 1995, 43, 27-32. [CrossRef]

22. Ivănescu, B.; Tuchilus, C.; Corciovă, A.; Lungu, C.; Mihai, C.T.; Gheldiu, A.M.; Vlase, L. Antioxidant, antimicrobial and cytotoxic activity of Tanacetum vulgare, Tanacetum corymbosum and Tanacetum macrophyllum extracts. Farmacia 2018, 66, $282-288$.

23. Mockute, D.; Judzentiene, A. Composition of the essential oils of Tanacetum vulgare L. growing wild in Vilnius District (Lithuania). J. Essent. Oil Res. 2004, 16, 550-553. [CrossRef]

24. Judzentiene, A.; Mockute, D. The inflorescence and leaf oils of Tanacetum vulgare L. var. vulgare growing wild in Lithuania. Biochem. Syst. Ecol. 2005, 33, 487-498. [CrossRef]

25. Di Napoli, M.; Maresca, V.; Varcamonti, M.; Bruno, M.; Badalamenti, N.; Basile, A.; Zanfardino, A. (+)-(E)-hrysanthenyl acetate: A molecule with interesting biological properties contained in the Anthemis secundiramea (Asteraceae) flowers. Appl. Sci. 2020, 10, 6808. [CrossRef]

26. Barra, A. Factors affecting chemical variability of essential oils: A review of recent developments. Nat. Prod. Comm. 2009, 4, 147-1154. [CrossRef]

27. Johnson, C.B.; Kirby, J.; Naxakis, G.; Pearson, S. Substantial UV-mediated induction of essential oils in sweet basil (Ocimum basilicum L.). Phytochemistry 1999, 51, 507-510. [CrossRef]

28. Peer, W.A.; Langenheim, J.H. Influence of phytochrome on leaf monoterpene variation in Satureja douglasii. Biochem. Syst. Ecol. 1998, 26, 25-34. [CrossRef]

29. Li, Y.; Kong, D.; Fu, Y.; Sussman, M.R.; Wu, H. The effect of developmental and environmental factors on secondary metabolites in medicinal plants. Plant Physiol. Biochem. 2020, 148, 80-89. [CrossRef] [PubMed]

30. Palà-Paùl, J.; Perèz-Alonso, M.J.; Velasco-Neguerela, A.; Palà-Paùl, R.; Sanz, J.; Conejero, F.C.O. Seasonal variation in chemical constituents of Santolina rosmarinifolia L. ssp. rosmarinifolia. Biochem. Syst. Ecol. 2001, 29, 663-672. [CrossRef]

31. Taveira, F.S.N.; de Lima, W.N.; Andrade, E.H.A.; Maia, J.G.S. Seasonal essential oil variation of Aniba canelilla. Biochem. Syst. Ecol. 2003, 31, 69-75. [CrossRef]

32. Boira, H.; Blanquer, A. Environmental factors affecting chemical variability of essential oils in Thymus piperella L. Biochem. Syst. Ecol. 1998, 26, 811-822. [CrossRef]

33. Palà-Paùl, J.; Usano-Alemany, J.; Soria, A.C.; Pèrez-Alonso, M.; Brophy, J.J. Essential oil composition of Erygium campestre L. growing in different soil types. A preliminary study. Nat. Prod. Comm. 2008, 3, 1121-1126. [CrossRef]

34. Mączka, W.; Duda-Madej, A.; Górny, A.; Grabarczyk, M.; Wińska, K. Can eucalyptol replace antibiotics? Molecules 2021, $26,4933$. [CrossRef] [PubMed]

35. Formisano, C.; Senatore, F.; Bruno, M.; Rosselli, S.; Bellone, G.; Spadaro, V. Essential oil composition of Tanacetum vulgare subsp. siculum (Guss.) Raimondo et Spadaro (Asteraceae) from Sicily. Nat. Prod. Comm. 2009, 4, 567-570. 
36. Hyeon, H.; Hyun, H.B.; Go, B.; Kim, S.C.; Jung, Y.-H.; Ham, Y.-M. Profiles of essential oils and correlations with phenolic acids and primary metabolites in flower buds of Magnolia heptapeta and Magnolia denudata var. purpurascens. Molecules 2022, $27,221$. [CrossRef] [PubMed]

37. Clancy, M.V.; Haberer, G.; Jud, W.; Niederbacher, B.; Niederbacher, S.; Senft, M.; Zytynska, S.E.; Weisser, W.W.; Schnitzler, J.P. Under fire-simultaneous volatilome and transcriptome analysis unravels fine-scale responses of tansy chemotypes to dual herbivore attack. BMC Plant Biol. 2020, 20, 551. [CrossRef] [PubMed] 